\title{
The major accident at Fukushima
}

\section{Seismic, nuclear and medical considerations}

ACADÉMIE DES SCIENCES

edpsciences

17, avenue du Hoggar

Parc d'activités de Courtabœuf, BP 112

91944 Les Ulis Cedex A, France 


\section{Imprimé en France}

(C) 2012, EDP Sciences, 17, avenue du Hoggar, BP 112, Parc d'activités de Courtaboeuf, 91944 Les Ulis Cedex A

Tous droits de traduction, d'adaptation et de reproduction par tous procédés réservés pour tous pays. Toute reproduction ou représentation intégrale ou partielle, par quelque procédé que ce soit, des pages publiées dans le présent ouvrage, faite sans l'autorisation de l'éditeur est illicite et constitue une contrefaçon. Seules sont autorisées, d'une part, les reproductions strictement réservées à l'usage privé du copiste et non destinées à une utilisation collective, et d'autre part, les courtes citations justifiées par le caractère scientifique ou d'information de l'oeuvre dans laquelle elles sont incorporées (art. L. 122-4, L. $122-5$ et L. 335-2 du Code de la propriété intellectuelle). Des photocopies payantes peuvent être réalisées avec l'accord de l'éditeur. S'adresser au : Centre français d'exploitation du droit de copie, 3, rue Hautefeuille, 75006 Paris. Tél. : 0143269535. 
Report of working group Solidarity for Japan

Chaired by

Alain CARPENTIER, President of the Académie des sciences, with

Jacques FRIEDEL, former President of the Académie des sciences, for the part Megaseisms and megatsunamis

Édouard BRÉZIN, former President of the Académie des sciences, for the part The nuclear accident

Étienne-Émile BAULIEU, former President of the Académie des sciences, for the part Consequences on health and the environment 
